\title{
Exhaust Nozzle Plume Effects on Sonic Boom Test Results for Vectored Nozzles
}

Raymond Castner

Glenn Research Center, Cleveland, Ohio 


\section{NASA STI Program . . . in Profile}

Since its founding, NASA has been dedicated to the advancement of aeronautics and space science. The NASA Scientific and Technical Information (STI) program plays a key part in helping NASA maintain this important role.

The NASA STI Program operates under the auspices of the Agency Chief Information Officer. It collects, organizes, provides for archiving, and disseminates NASA's STI. The NASA STI program provides access to the NASA Aeronautics and Space Database and its public interface, the NASA Technical Reports Server, thus providing one of the largest collections of aeronautical and space science STI in the world. Results are published in both non-NASA channels and by NASA in the NASA STI Report Series, which includes the following report types:

- TECHNICAL PUBLICATION. Reports of completed research or a major significant phase of research that present the results of NASA programs and include extensive data or theoretical analysis. Includes compilations of significant scientific and technical data and information deemed to be of continuing reference value. NASA counterpart of peer-reviewed formal professional papers but has less stringent limitations on manuscript length and extent of graphic presentations.

- TECHNICAL MEMORANDUM. Scientific and technical findings that are preliminary or of specialized interest, e.g., quick release reports, working papers, and bibliographies that contain minimal annotation. Does not contain extensive analysis.

- CONTRACTOR REPORT. Scientific and technical findings by NASA-sponsored contractors and grantees.
- CONFERENCE PUBLICATION. Collected papers from scientific and technical conferences, symposia, seminars, or other meetings sponsored or cosponsored by NASA.

- SPECIAL PUBLICATION. Scientific, technical, or historical information from NASA programs, projects, and missions, often concerned with subjects having substantial public interest.

- TECHNICAL TRANSLATION. Englishlanguage translations of foreign scientific and technical material pertinent to NASA's mission.

Specialized services also include creating custom thesauri, building customized databases, organizing and publishing research results.

For more information about the NASA STI program, see the following:

- Access the NASA STI program home page at http://www.sti.nasa.gov

- E-mail your question via the Internet to help@ sti.nasa.gov

- Fax your question to the NASA STI Help Desk at $443-757-5803$

- Telephone the NASA STI Help Desk at 443-757-5802

- Write to: NASA Center for AeroSpace Information (CASI) 7115 Standard Drive Hanover, MD 21076-1320 
NASA/TM-2012-217229

AIAA-2011-5974

\section{Exhaust Nozzle Plume Effects on Sonic Boom Test Results for Vectored Nozzles}

Raymond Castner

Glenn Research Center, Cleveland, Ohio

Prepared for the

47th Joint Propulsion Conference and Exhibit

cosponsored by AIAA, ASME, SAE, and ASEE

San Diego, California, July 31-August 3, 2011

National Aeronautics and

Space Administration

Glenn Research Center

Cleveland, Ohio 44135 


\section{Acknowledgments}

John Jones provided design and fabrication of the wind tunnel model and support systems. Facility support was provided by Scott Smrdel, Bob Clark and Bob McClusky, at the NASA Glenn Research Center. Test assistance was also provided by Manan Vyas. Flight data was provided by Ed Haering at the NASA Dryden Research Center. This work was funded by the NASA Fundamental Aeronautics Program, Supersonics Project.

Trade names and trademarks are used in this report for identification only. Their usage does not constitute an official endorsement, either expressed or implied, by the National Aeronautics and Space Administration.

This work was sponsored by the Fundamental Aeronautics Program at the NASA Glenn Research Center.

Level of Review: This material has been technically reviewed by technical management.

Available from

NASA Center for Aerospace Information 7115 Standard Drive

Hanover, MD 21076-1320
National Technical Information Service 5301 Shawnee Road Alexandria, VA 22312 


\title{
Exhaust Nozzle Plume Effects on Sonic Boom Test Results for Vectored Nozzles
}

\author{
Raymond Castner \\ National Aeronautics and Space Administration \\ Glenn Research Center \\ Cleveland, Ohio 44135
}

\begin{abstract}
Reducing or eliminating the operational restrictions of supersonic aircraft over populated areas has led to extensive research at NASA. Restrictions were due to the disturbance of the sonic boom, caused by the coalescence of shock waves formed off the aircraft. Recent work has been performed to reduce the magnitude of the sonic boom N-wave generated by airplane components with a focus on shock waves caused by the exhaust nozzle plume. Previous Computational Fluid Dynamics (CFD) analysis showed how the shock wave formed at the nozzle lip interacts with the nozzle boat-tail expansion wave. An experiment was conducted in the 1- by 1-foot Supersonic Wind Tunnel (SWT) at the NASA Glenn Research Center. Results show how the shock generated at the nozzle lip affects the near field pressure signature, and thereby the potential sonic boom contribution for a nozzle at vector angles from $3^{\circ}$ to $8^{\circ}$. The experiment was based on the NASA F-15 nozzle used in the Lift and Nozzle Change Effects on Tail Shock experiment, which possessed a large external boat-tail angle. In this case, the large boat-tail angle caused a dramatic expansion, which dominated the near field pressure signature. The impact of nozzle vector angle and nozzle pressure ratio are summarized.
\end{abstract}

\section{Nomenclature}

D test nozzle diameter, inches

NPR nozzle pressure ratio $=\mathrm{P}_{\mathrm{t}} / \mathrm{P}_{\infty}$

$\mathrm{P} \quad$ local static pressure, psia

$\mathrm{P}_{\mathrm{t}} \quad$ total pressure in nozzle, psia

$\mathrm{P}_{\infty} \quad$ free stream static pressure, $\mathrm{psia}$

$\Delta \mathrm{P} / \mathrm{P} \quad\left(\mathrm{P}-\mathrm{P}_{\infty}\right) / \mathrm{P}_{\infty}($ also $\mathrm{Cp})$

$\mathrm{t}$ time, seconds

$\mathrm{x} \quad$ axial distance from jet simulator nosecone tip, inches

y distance from nozzle centerline, inches

\subsection{Introduction}

NASA has been conducting extensive research to reduce the sonic boom signature caused by supersonic flight speeds. The Supersonics Project, under NASA's Fundamental Aeronautics Program, studies a number of technology challenges related to supersonic flight. These challenges include sonic boom, supersonic cruise efficiency, airport noise, high altitude emissions, lightweight engines/airframes, and multidisciplinary design. The present work was relevant to sonic boom reduction, which aims to mitigate the disturbance caused by the sonic boom and potentially remove the present aircraft operational restriction of supersonic flight over water only. A sonic boom is generated by coalescing shock waves and expansion fans formed by aircraft components, which generate an $\mathrm{N}$-wave. The $\mathrm{N}$-wave consists of a rise in pressure versus time as the aircraft "bow-wave" passes over an observer, followed by a reduction in pressure, and finally a return to atmospheric pressure. Previous work by NASA, such as the Shaped Sonic 
Boom Demonstrator (Ref. 1) (SSBD) and the Quiet Spike, (Ref. 2) has studied how the sonic boom signature generated by the front of the aircraft can be reduced with aircraft shaping. Complementary work was desired to reduce the sonic boom signature in the aft portion of the sonic boom N-wave, which in turn would decrease the peak-to-peak magnitude and result in a reduced sonic boom. This could be accomplished through the study of how aft components, such as the tail, nacelles, and nozzles contributed to the right hand portion of the sonic boom N-wave.

Early work on exhaust nozzle contribution to sonic boom included a report by Putnam and Capone (Ref. 4), and another by Barger and Melson (Ref. 5). In the work by Putnam and Capone, nozzles were tested from a fully-expanded Mach 1.7 nozzle to a fully-expanded Mach 2.9 nozzle. Their study was conducted in a wind tunnel, where near-field pressure measurements were made at one nozzle diameter away from the model. Wind tunnel conditions were Mach 2.2 at a simulated altitude of 50,000 ft. In 2009, Castner (Ref. 6) performed a CFD analysis, where it was determined that over-expanded and underexpanded operation of a nozzle had an effect on the $\mathrm{N}$-wave boom signature. The work demonstrated the feasibility of reducing the magnitude of the sonic boom N-wave by controlling the nozzle plume interaction with the nozzle boat-tail flow structure. Under-expanded exhaust nozzle flow had a favorable result on near field pressure signatures, suggesting that the nozzle plume shock location could be controlled through control of nozzle pressure or nozzle divergent section geometry.

A complementary activity was performed to study nozzle plume effects in a flight environment. The flight test was performed using the NASA F-15 "Active" aircraft used for the Lift and Nozzle Change Effects on Tail Shock (LaNCETS) experiment (Ref. 3). The research approach for this experiment was to alter the aircraft shock structure by: (1) changing the lift distribution with canard position, (2) changing the plume shape with under-expanded and over-expanded nozzle flow, and (3) changing the plume shape using thrust vectoring. The test measured resulting shocks with a probing aircraft and used results to validate predictive tools.

The capability to test small-scale models in NASA GRC's 1- by 1-foot Supersonic Wind Tunnel (SWT) was developed to validate results obtained for supersonic nozzle concepts. This capability was utilized for a fundamental study of the LaNCETS vectored exhaust nozzle concept. The purpose of this report is to present the wind tunnel test results. The present work studied the effects of the vectored nozzle exhaust plume on near field pressure signatures, which directly correlate to sonic boom. Wind tunnel test results include schlieren images of the nozzle exhaust shock structure and near-field static pressure profiles as collected from a static pressure probe.

\subsection{Background}

The effects of under-expanded and over-expanded nozzle flow on the near field pressure signature was computed for a baseline nozzle (Ref. 6). Changes in nozzle pressure ratio (NPR) caused changes in the magnitude of the observed pressure signature, which would correspond to a change in the observed sonic boom signature. Figure 1 shows what happens when far-field pressure signatures were propagated to the ground. It was evident that as NPR was increased, the peak-to-peak magnitude for the right hand portion of the pressure signature was decreased.

As a separate activity, a flight test was performed using the NASA F-15 "Active" aircraft (tail number 837) for the LaNCETS experiment (Ref. 3). The research approach for this experiment was to alter the shock structure of NASA's unique NF-15B airplane by: (1) changing the lift distribution with canard positions, (2) changing the plume shape with under-expanded and over-expanded nozzle flow, and (3) changing the plume shape using thrust vectoring. The test measured resulting shocks with a probing aircraft, NASA's F-15B with tail number 836. Flight test results were used to validate predictive tools.

Figure 2 demonstrates results collected from the flight test experiment, and also indicates that a $3^{\circ}$ and $6^{\circ}$ vector angle did not demonstrate significant differences in any peak values for the aircraft pressure signature. Results for the $8^{\circ}$ vector angle are not shown, but were similar. For the flight test, a positive angle was an upward vector angle. 


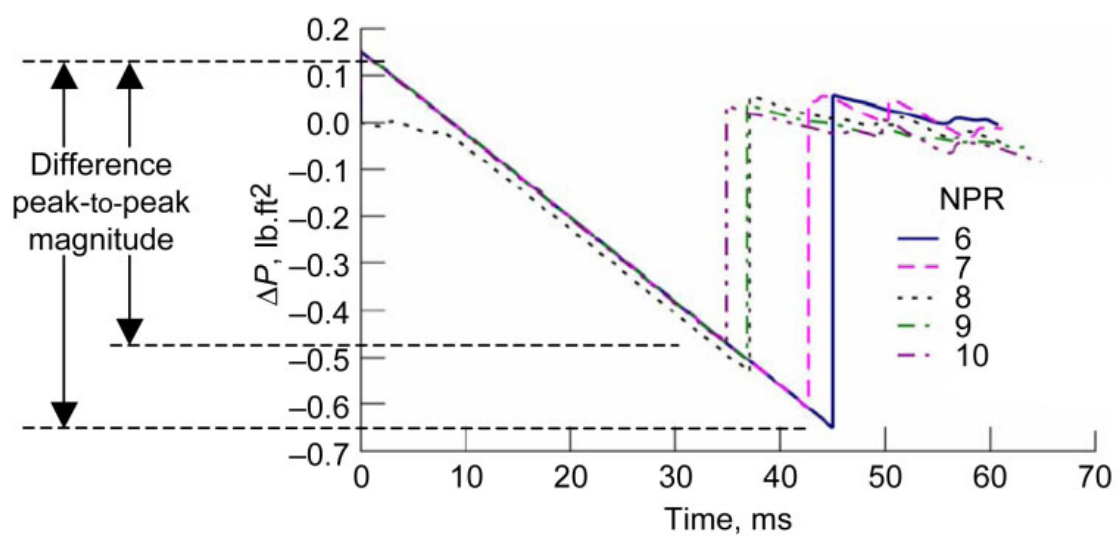

Figure 1.-Estimated sonic boom signature at ground through an ideal atmosphere, NPR 6 to 10.

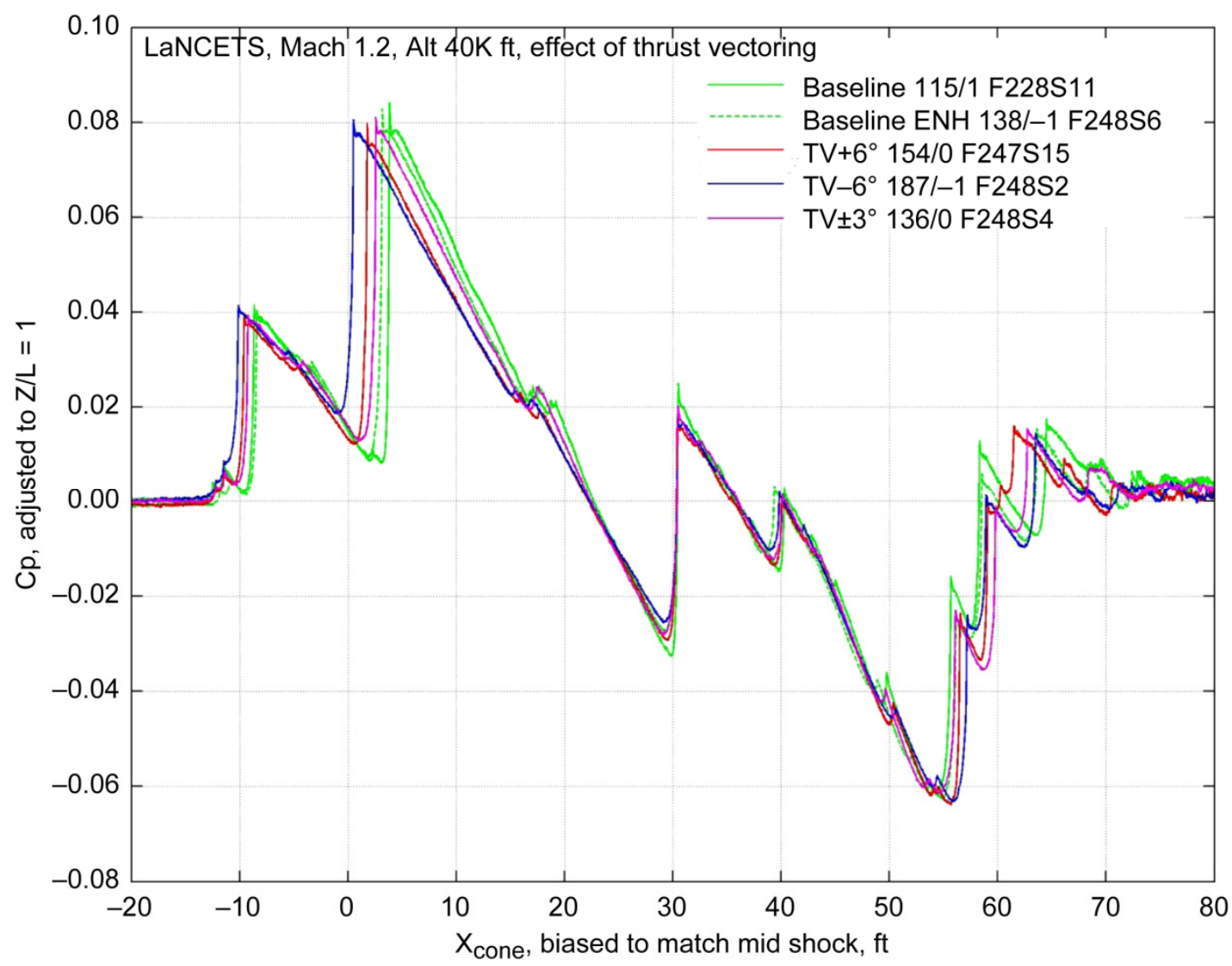

Figure 2.-LaNCETS aircraft $\triangle \mathrm{P} / \mathrm{P}$ flight test results for Mach 1.2 at $40,000 \mathrm{ft}$ altitude, nozzle vector angle of $\pm 3^{\circ}$ and $\pm 6^{\circ}$.

In addition to the flight test, small-scale tests were conducted in the NASA GRC 1- by 1-foot SWT to collect wind tunnel data for isolated nozzles. Results were intended to provide fundamental understanding of the effect of a vectored nozzle on vehicle pressure signature. 


\subsection{Test Setup}

The small-scale wind tunnel model, tested in the GRC 1- by 1-foot SWT was designed to operate across a variety of wind tunnel Mach numbers, nozzle pressure ratios, and simulated altitudes. This section is to review the wind tunnel model, instrumentation, and location in the wind tunnel.

\subsection{Model}

The wind tunnel model consisted of three major parts: the upper plenum, the strut, and the lower plenum (as displayed in Fig. 3). A photo of the rig installation is also provided in Figure 4. The upper plenum design was 1-in. outer diameter, and had an overall length from the nosecone to the nozzle exit of 8.21 in. Both nosecone and nozzle were attached with fine pitched threaded connections. The support strut was $0.35 \mathrm{in}$. in thickness and contained nine passages to supply airflow. Air supply lines were 0.25 in. diameter, and the passages supplied 90 psia of pressure to achieve 20 psia at the nozzle inlet for test conditions at 50,000 ft altitude. To accommodate larger nozzles and testing at lower altitudes, the

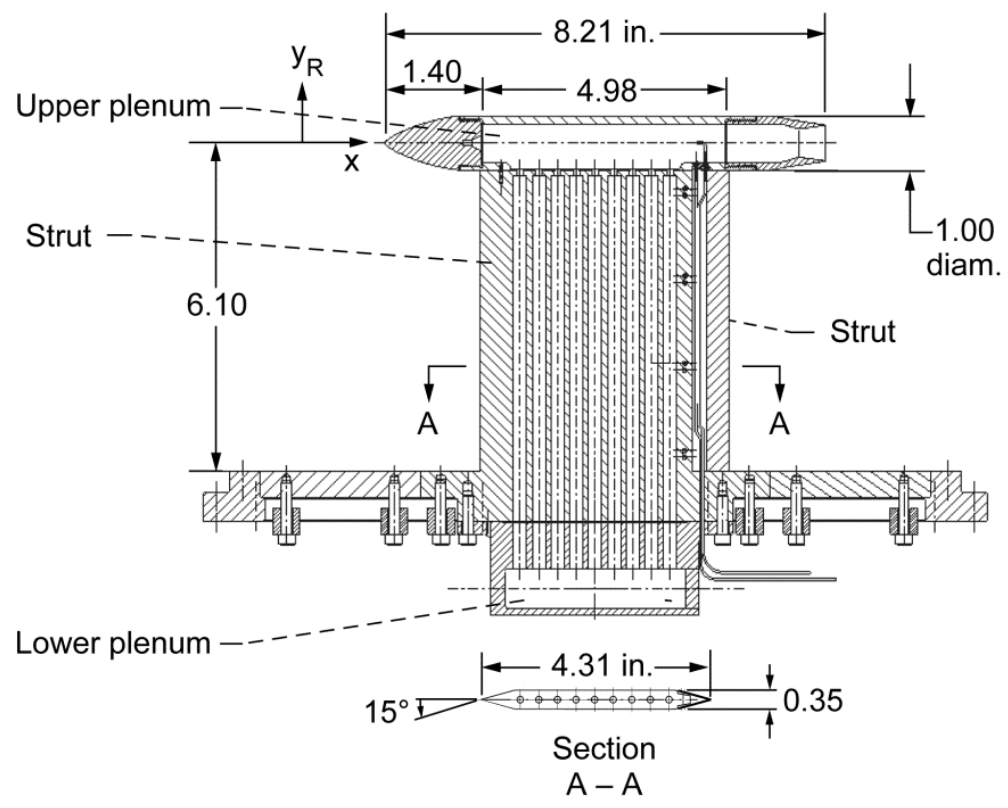

Figure 3.-Wind tunnel model cut-away, dimensions in inches.

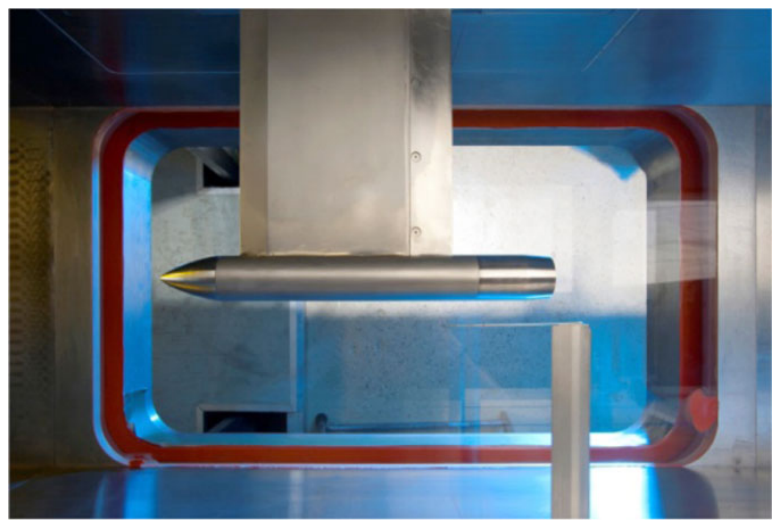

Figure 4.-Wind tunnel model photograph, downward view through the top schlieren window. 
maximum design pressure at the strut was 233 psia, to achieve 52 psia at the nozzle inlet. Choked orifice holes were needed on top of the strut supply lines to obtain required mass flow. Orifice holes were 0.210 in. diameter. Air was supplied to the bottom of the strut through a lower plenum by the centralized 450 psig pressurized air system at the NASA Glenn Research Center.

The location of the strut and model was designed to move forward and aft in the wind tunnel test section. This was accomplished with a slot, allowing 6 in. of overall travel. In this manner the rig location could be modified to avoid unforeseen wind tunnel flow effects or shock wave reflections. Manual changes to rig location could only be made between tests with the wind tunnel turned off.

\subsection{Instrumentation}

NPR was determined based on mass flow measurement and nozzle throat diameter. Sonic flow equations for a venturi were used from Blevins (Ref. 7) to perform this calculation. An external static pressure probe was designed to survey near-field static pressure profiles at one nozzle diameter above the rig centerline. The static pressure probe was mounted on an airfoil probe support, and a sliding ball screw actuator, from the opposite side of the tunnel. The probe passed through the tunnel sidewall and the actuator was installed in an enclosure to match the tunnel pressure. The overall assembly, showing the probe location, is provided in Figure 5.

The static pressure probe had a capability to travel axially from $\mathrm{x} / \mathrm{D}=6.9$ to 13.5 to capture pressure profiles, starting $0.65 \mathrm{in}$. upstream of the nozzle exit, and extending downstream to where the plume interacts with the tunnel/wall shock reflection. The probe design, based on Pickney (Ref. 8) and presented in Figure 6, had less sensitivity than a traditional static pressure probe design to angle of attack, while achieving relaxation of static pressure at the location of the measurement ports. These probes were mounted on a $3 / 8$ in. thick airfoil strut (Fig. 5), allowing 5.625 in. of probe length between the static pressure holes and the airfoil support.

The model was placed between two transparent sidewalls in the 1- by 1-foot SWT for schlieren photography.

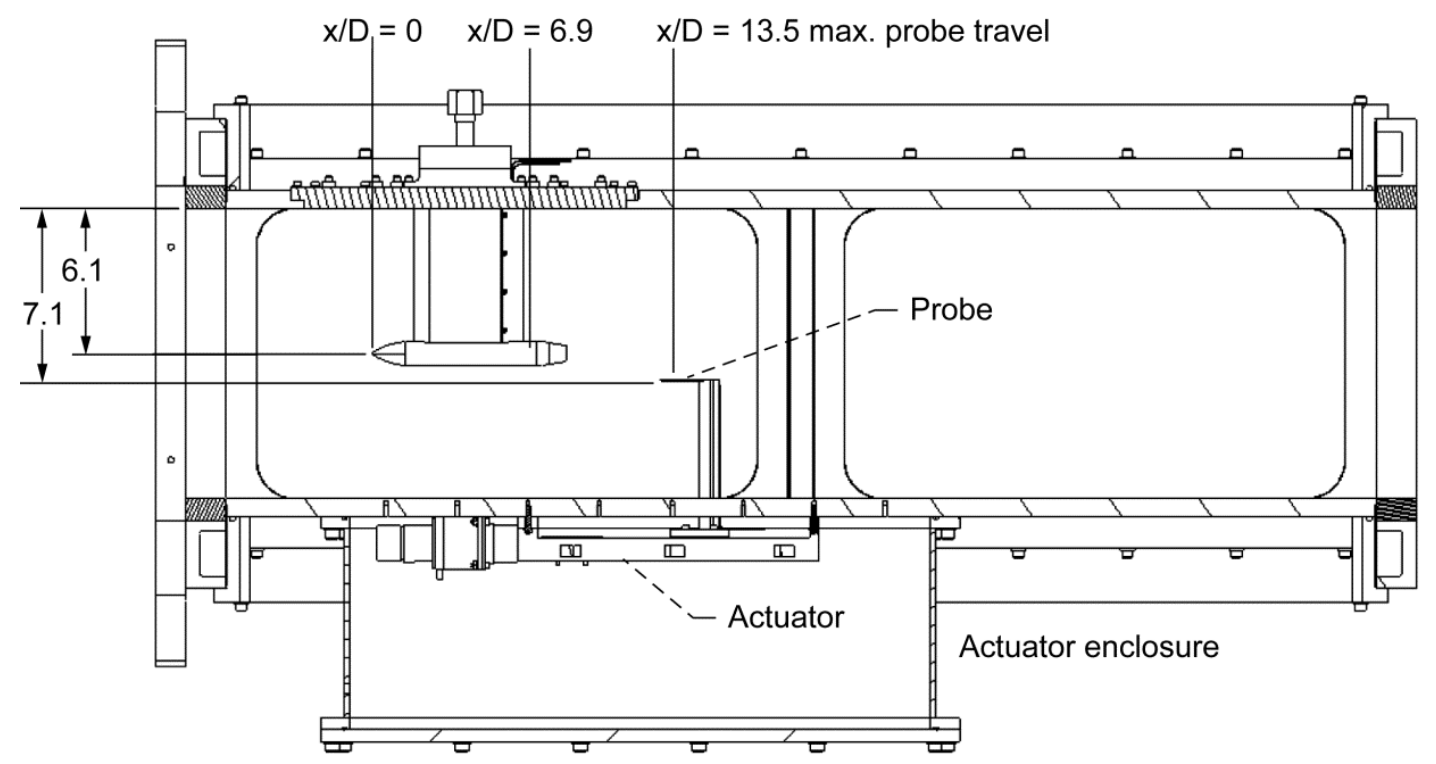

Figure 5.-Wind tunnel model cross section as installed in the 1- by 1-foot SWT test section, dimensions in inches. 


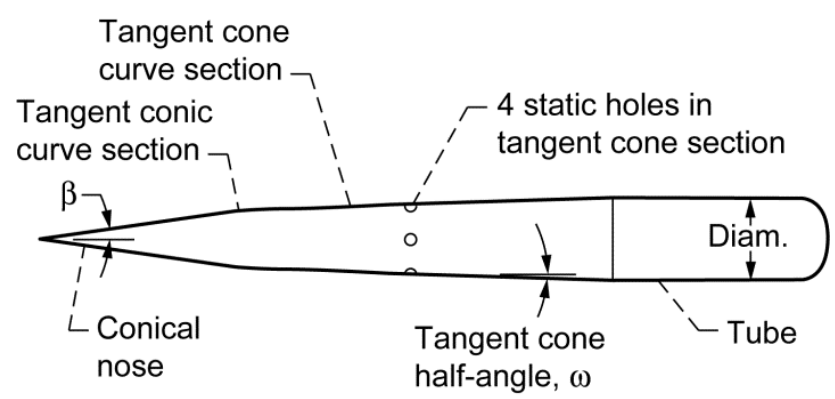

Figure 6.-Short static pressure probe design (Ref. 7).

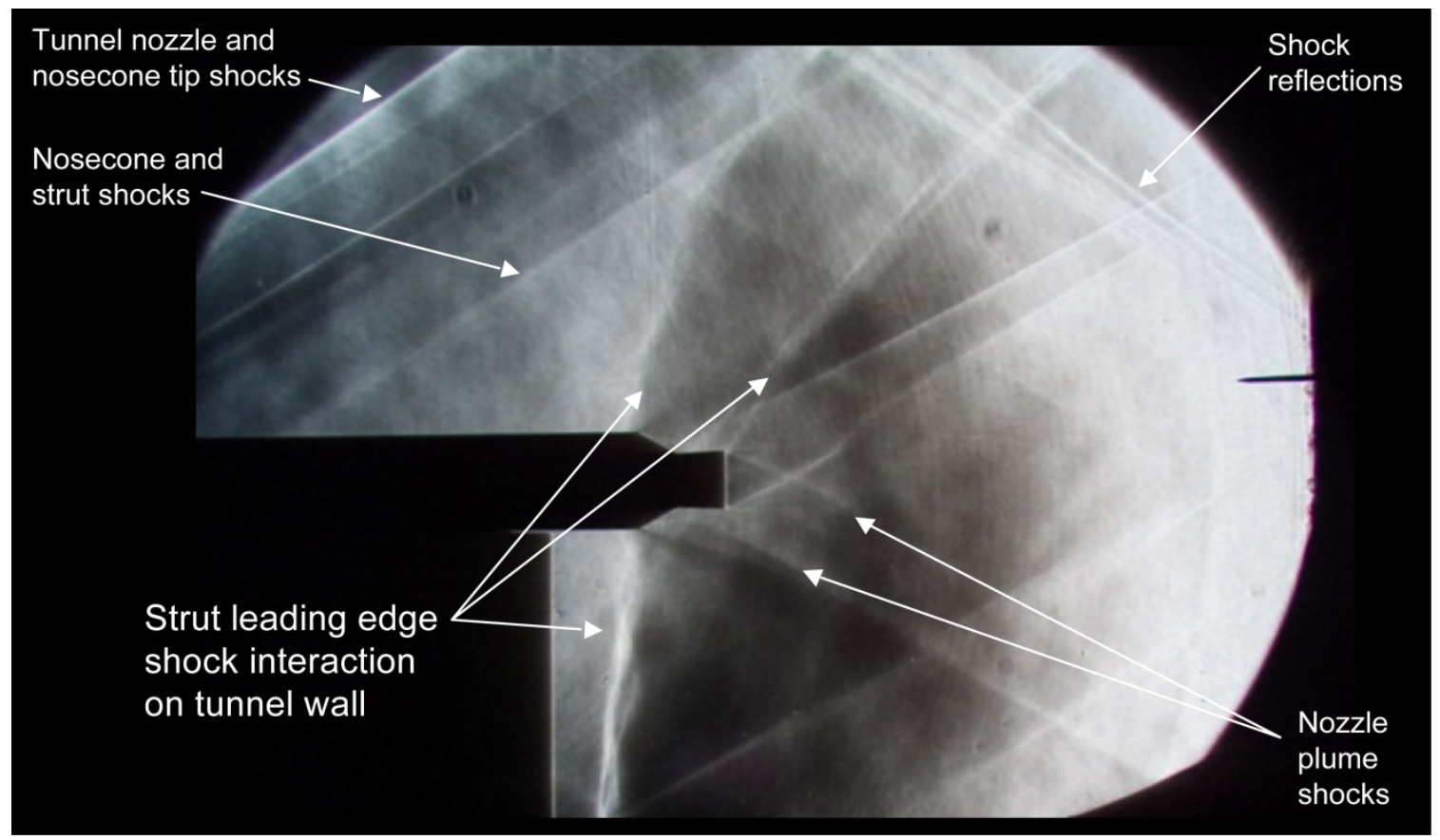

Figure 7.-Schlieren image of tunnel shock structure.

\subsection{Model Location}

The location of the model in the wind tunnel was a concern. Correct model location was necessary to provide a clean nozzle flow-field at the correct Mach number. The nozzle flow-field also had to be free of shock reflections and shock interactions. A schlieren image, Figure 7, was collected with the nozzle operating at an NPR of 8. Six types of shock waves were evident. It was a challenge to place the nozzle inside these shocks and provide a clean nozzle flow-field. Sources for shock waves in the tunnel were:

1. Wind tunnel nozzle block

2. Nosecone tip

3. Nosecone and strut interaction

4. Tunnel wall reflections

5. Strut leading edge

6. Nozzle plume (shock of interest) 
The shock wave from the wind tunnel nozzle block was generated by a small step in the tunnel wall. This step was located at the end of the interchangeable wind tunnel throat block, upstream of the model. Through careful model placement, the shock wave from the nosecone tip was co-located with the wind tunnel nozzle block shock. Shock waves from the nosecone and strut interaction were set by the strut geometry. This model design was kept as short as possible to avoid the wind tunnel wall reflections. The strut leading edge shock wave was a lateral shock wave that impacted the wind tunnel walls in a plane that appeared to interfere with the nozzle exhaust. However, the placement of this shock interaction was on the wind tunnel wall, 6 in. away from the nozzle plume. This interaction location was validated by pretest calculations and flow visualization. Similarly, the strut trailing edge shock and expansion did not interfere with the nozzle plume. Finally, the nozzle plume shock structure is visible, which was the objective of the experiment.

To determine the interaction of the model strut shock wave with the wind tunnel glass sidewall, flow visualization was performed with a fluorescent paint and oil mixture. Results indicated clean flow at the nozzle location (Ref. 9).

\subsection{Nozzle}

The test nozzle was a 1:51.5 scale model of the nozzle installed on the NASA F-15 "Active" aircraft. The nozzles, (see samples for $0^{\circ}$ vector angle in Fig. 8 and for $8^{\circ}$ vector angle in Fig. 9) had convergentdivergent geometry with an area ratio of 1.5 and a fully expanded NPR of 6.2 at Mach 2.0. Tests were run at Mach 2.0 to reduce the impact of shock reflections on the test model. However, LaNCETS flight data for vectored nozzle configurations were collected at Mach 1.2 and 1.4. The difference in Mach number between the flight experiment and the wind tunnel test reflects the intent to provide fundamental understanding of the effect of a vectored nozzle on vehicle pressure signature, and not an intent to explicitly match the flight test data.

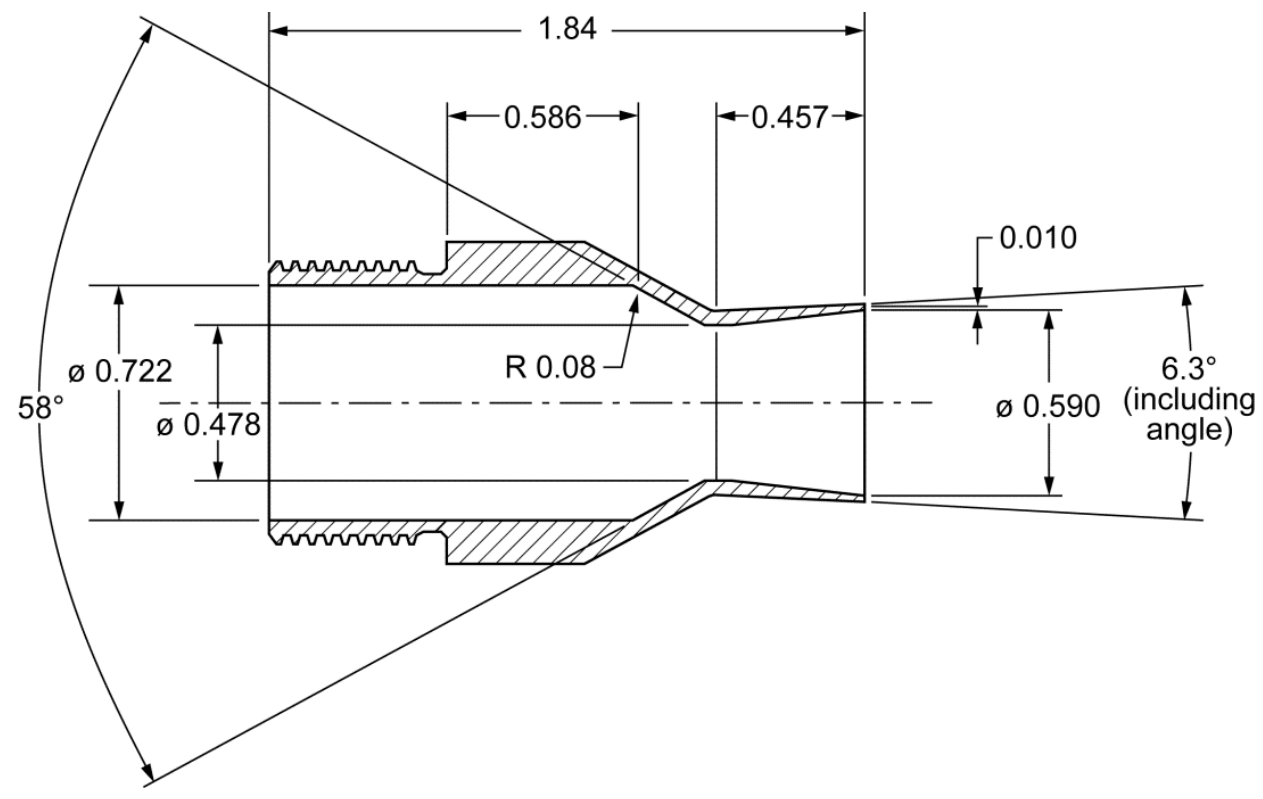

Figure 8.-The $0^{\circ}$ vectored nozzle, dimensions in inches. 


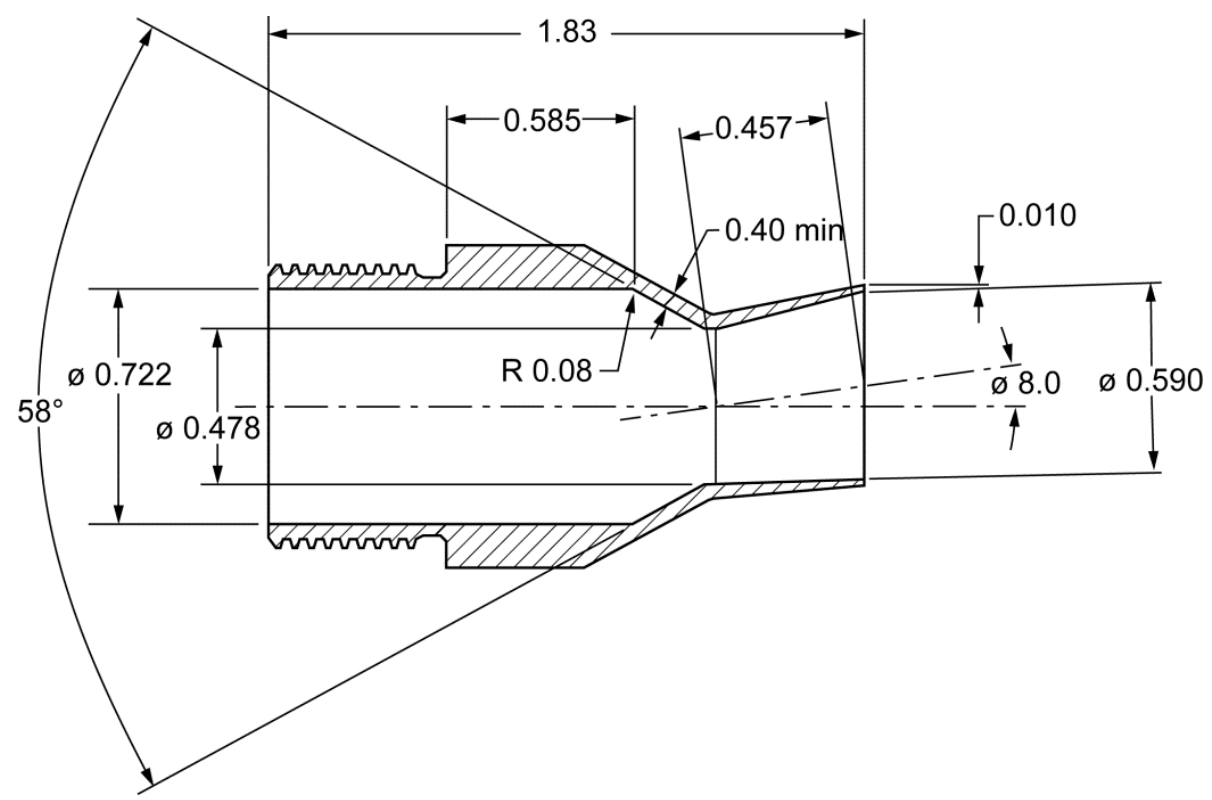

Figure $9 .-8^{\circ}$ vectored nozzle, dimensions in inches.

\subsection{Results}

\subsection{Near-Field Experimental Results}

In the 1- by 1-foot SWT, the experimental pressure signatures were measured at 1-diameter away from the nozzle centerline, collected on the side opposite the model support strut. Data were collected at this location due to space restrictions in a small wind tunnel, and is consistent with previous experiments (Ref. 9) and comparisons to far-field pressure data. Experimental pressure signatures $\left(\Delta \mathrm{P} / \mathrm{P}_{\infty}\right)$ were collected over a 6 in. axial distance, from $\mathrm{x} / \mathrm{D}=6.9$ to 13.5 , at 0.1 in. increments.

The near-field pressure dropped as flow expanded around the nozzle boat-tail. This expansion was followed by a rapid pressure rise due to the shock at the nozzle lip, and was followed by a secondary expansion and shock around the nozzle plume. As NPR was increased, the pressure rise due to the lip shock increased.

Figure 10 shows results for the $0^{\circ}$ vectored nozzle case. The plot demonstrates trends in the near field pressure as NPR was increased from 6.2 to 10; the strength of the nozzle lip shock increased, and the shock angle increased with respect to the nozzle exit centerline. The increase in shock strength caused a rise in the pressure, as measured at the first peak. The reduction in the first expansion was caused by the change in the shock angle, where the lip shock cut off the boat-tail expansion. As seen in results from Bui (Ref. 10), this nozzle had a dramatic boat-tail angle, and the external flow around the nozzle separated and formed an aerodynamic boat-tail, which created a low pressure expansion that dominated the pressure signature.

Nozzles were tested at $\pm 3^{\circ}, \pm 6^{\circ}$, and $\pm 8^{\circ}$ of vector angle. Results are presented in Figure 11 for the $-8^{\circ}$ vector angle. When compared to the $0^{\circ}$ vectored nozzle results, the boat-tail expansion did not dramatically change with vector angle at $-8^{\circ}$. At NPR $=6.2$ the lowest value of $\Delta \mathrm{P} / \mathrm{P}$ was -3.74 , and can be compared to a similar value of -3.84 for the $0^{\circ}$ vectored nozzle case. This is evidence that the high boat-tail angle caused an expansion that dominated the near field pressure signature. As the nozzle was vectored down, the shock from the nozzle lip was weaker than in the $0^{\circ}$ vector case. As shown at NPR of 6.2 , the values for the first peak in the pressure signature decreased to a $\Delta \mathrm{P} / \mathrm{P}$ of -0.150 for $-8^{\circ}$ versus the $\Delta \mathrm{P} / \mathrm{P}$ of -0.108 for $0^{\circ}$. Values for the secondary expansion and shock around the nozzle plume were not greatly affected. Increasing NPR from 6.2 to 12 demonstrated a similar trend as seen in the $0^{\circ}$ vector angle. The overall difference in peak-to-peak value of the pressure signature did not change significantly. 


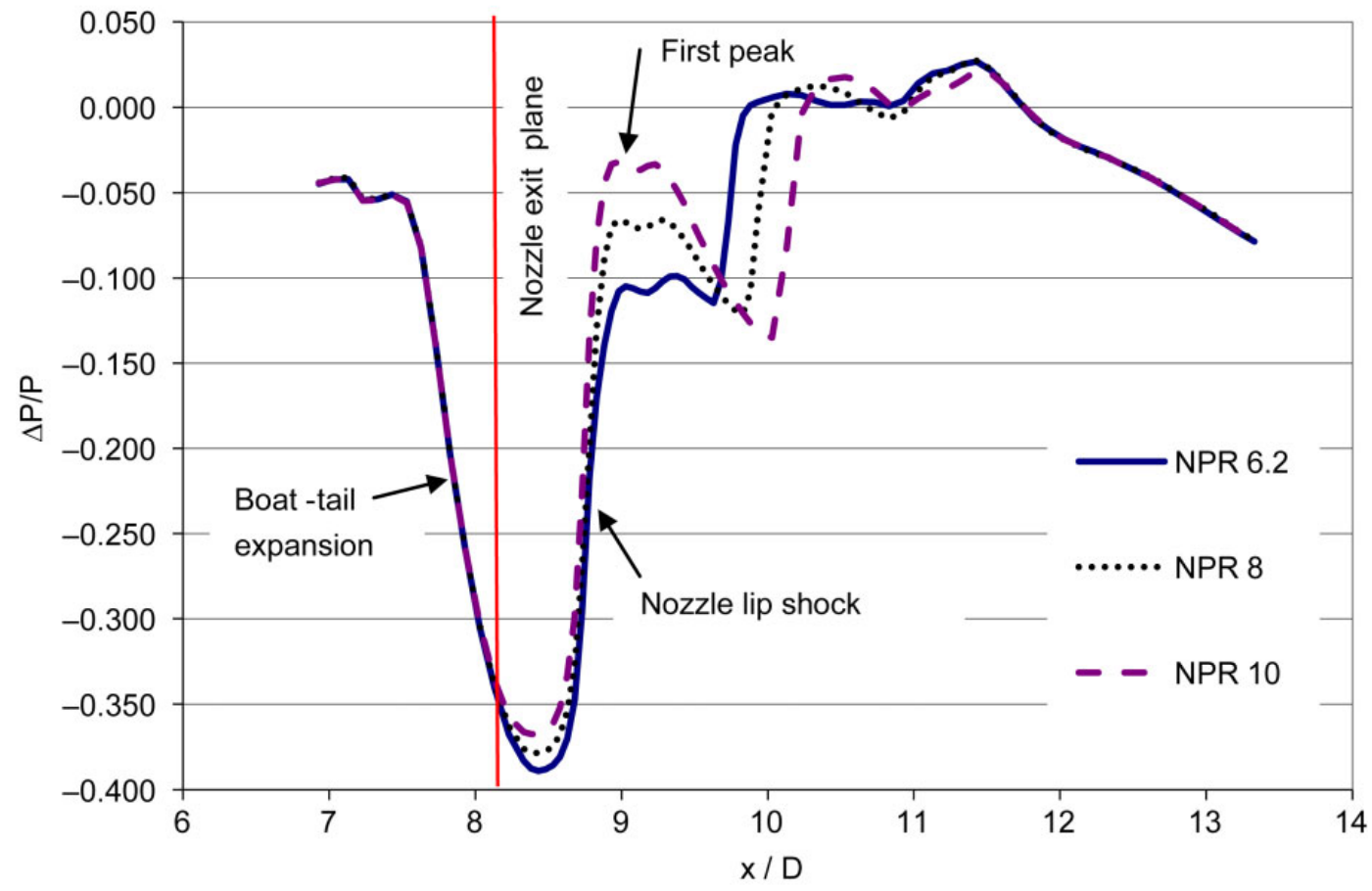

Figure 10. $-0^{\circ}$ vectored nozzle $\Delta P / P$, where $x=0$ at the nosecone tip.

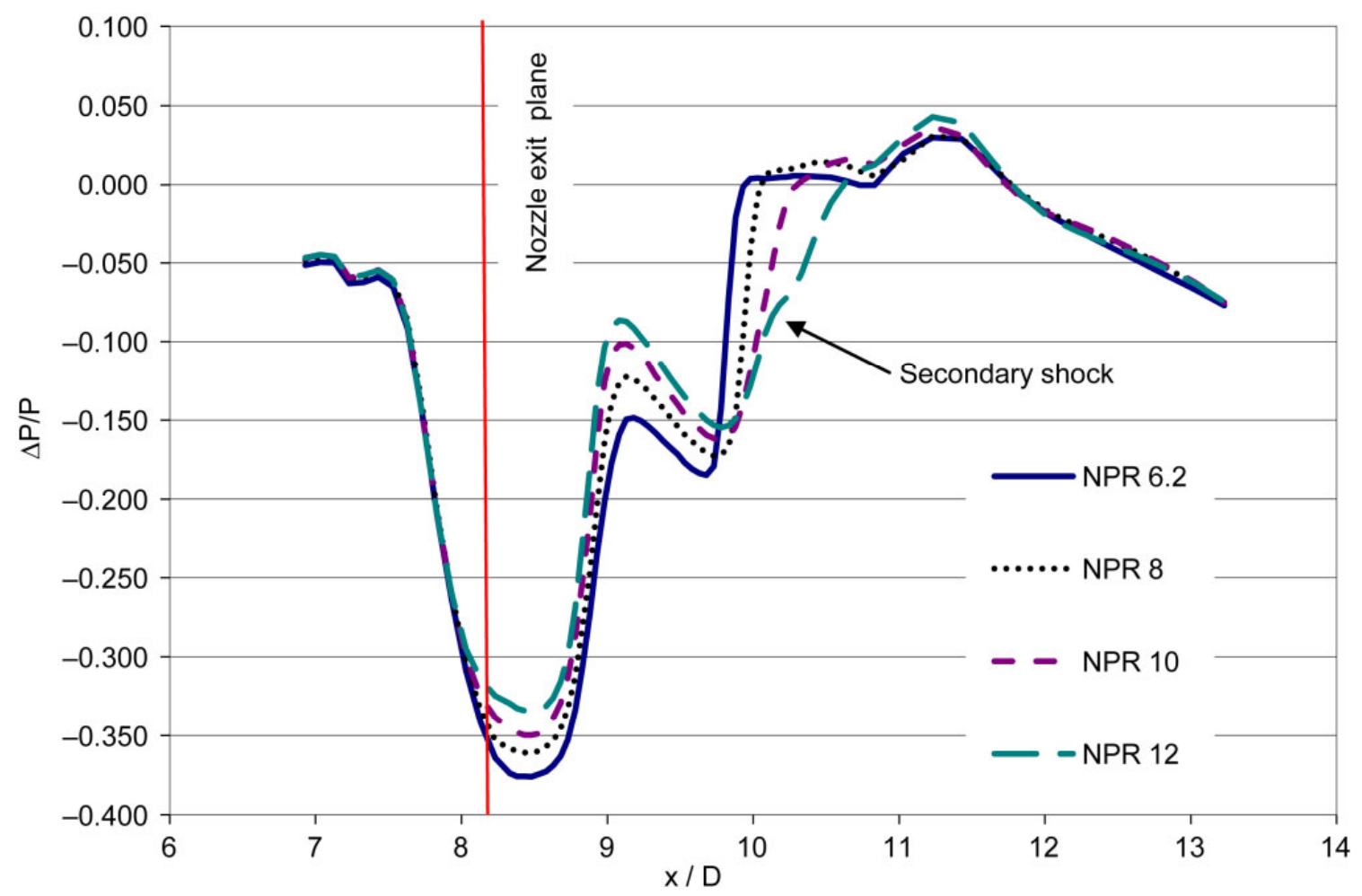

Figure 11.-Minus $8^{\circ}$ vectored nozzle $\Delta \mathrm{P} / \mathrm{P}$. 


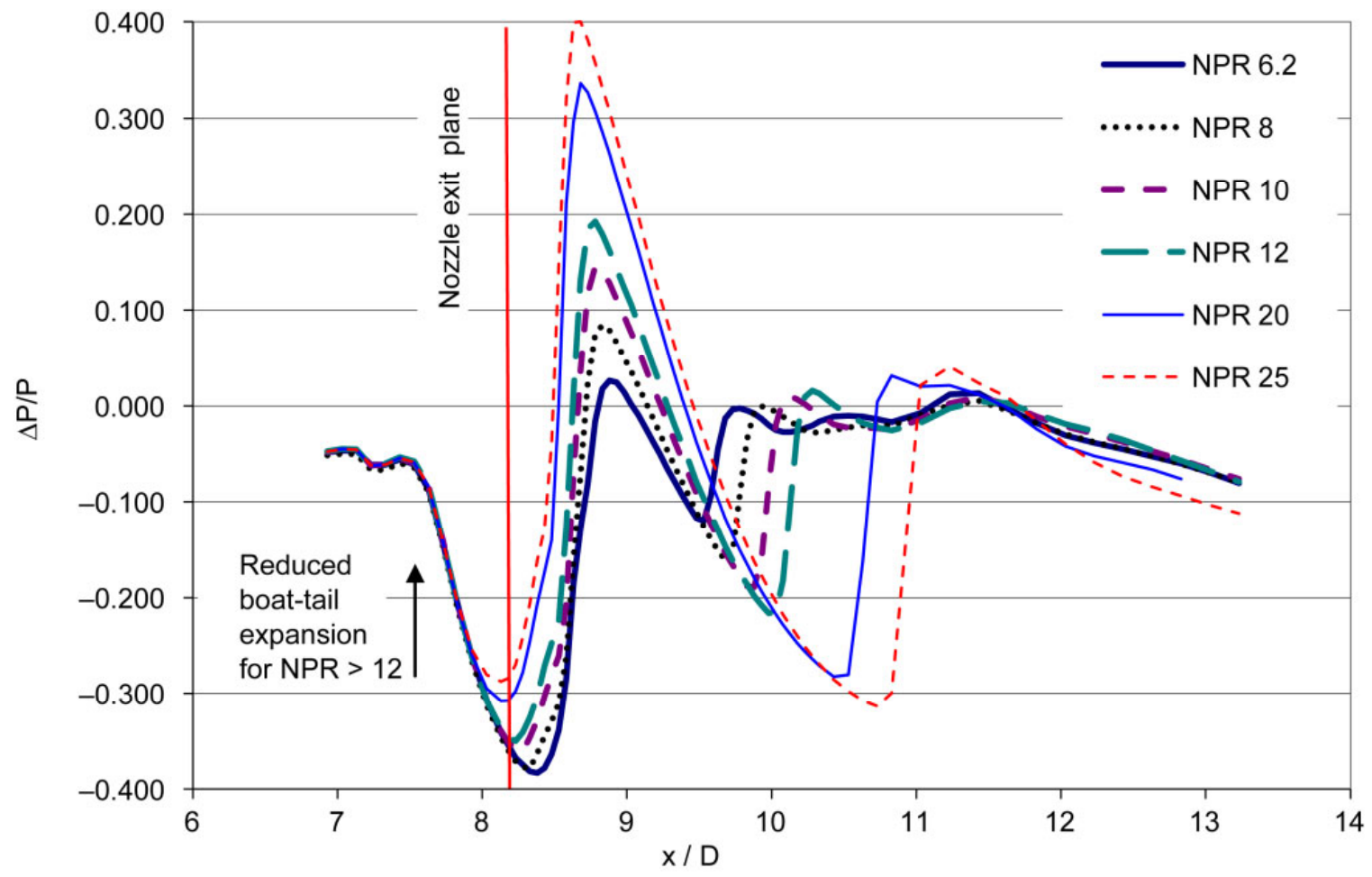

Figure 12.-Plus $8^{\circ}$ vectored nozzle $\Delta \mathrm{P} / \mathrm{P}$.

Results for the positive $8^{\circ}$ vector angle are displayed in Figure 12. Again the minimum value of -0.377 for $\Delta \mathrm{P} / \mathrm{P}$ did not change significantly, and demonstrated that the nozzle boat-tail angle again dominated the pressure signature. However, for the $8^{\circ}$ vector angle, the nozzle lip shock strength increased over both the -8 and $0^{\circ}$ vectored nozzle case, and measured 0.026 instead of -0.108 for the $0^{\circ}$ vectored nozzle case. As NPR was increased, the nozzle lip shock became stronger, and moved forward. This was the only case where NPR greater than 12 were tested to clearly demonstrate the trends for the nozzle lip shock, and to demonstrate that the strong lip shock could reduce the expansion around the nozzle boat-tail. This reduction is shown in Figure 12. These trends agree with previous supersonic $0^{\circ}$ vectored nozzle test results collected by Castner (Ref. 9). Based on the previous conclusions, if these shocks were allowed to propagate to the far-field, the effect would be a reduction in the peak-to-peak pressure differential.

In Figure 13, trends are shown for both increasing and decreasing nozzle vector angle for a constant NPR of 12. The result shows that the vector angle had an impact on the near field pressure signature. The effect was most noticeable in the increasing strength of the nozzle lip shock, but not on the level of boattail expansion. In the case of this nozzle design, the boat-tail expansion was the dominant flow feature. Past work on nozzles with lower boat-tail angle showed that increasing NPR had an impact on the peakto-peak level of the near field pressure signature. In this work, the vector angle was expected to have a similar effect and change the angle of the lip shock, but it did not. This result suggests that care should be taken to reduce the nozzle boat-tail angle as much as possible for low boom supersonic aircraft design. 


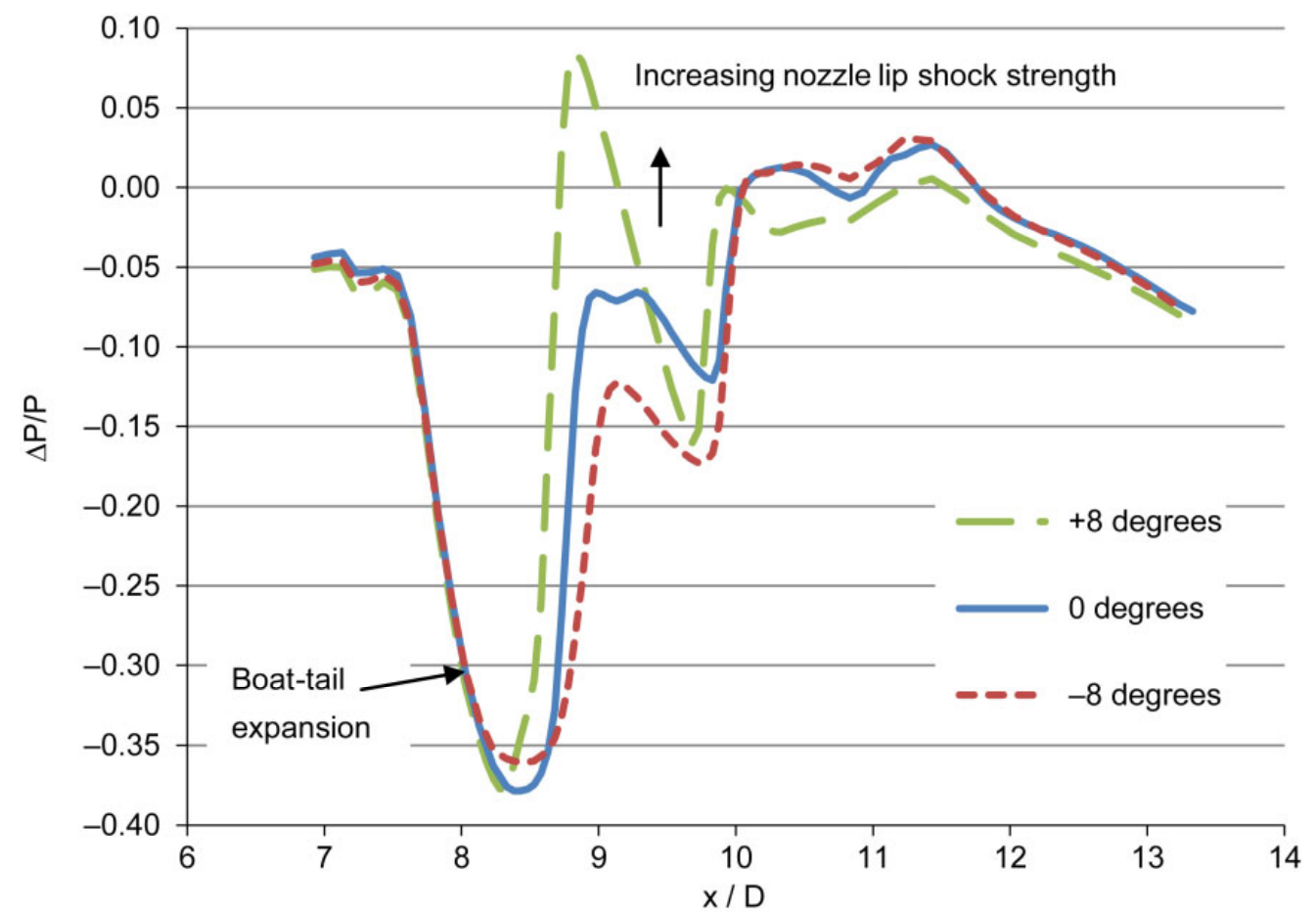

Figure 13. $-\Delta \mathrm{P} / \mathrm{P}$ for vector angles from $-8^{\circ}$ to $8^{\circ}$ at NPR 12.

\subsection{Schlieren Results}

The $0^{\circ}$ vector angle nozzle is displayed in Figure 14, where the location of the lip shock is highlighted for NPR of 8 . The lip shock is difficult to trace back to the nozzle lip, as it was formed off the interaction between the nozzle boat-tail and the lip shock. This could also be seen in CFD results for the nozzle geometry with exposed convergent and divergent flaps from Bui (Ref. 10), and is illustrated in Figure 15.

Further evidence of the dominant lip shock location can be observed in Figure 16 which shows a schlieren image from $-8^{\circ}$ of vector angle. In this case, the shock location was drawn from the $0^{\circ}$ case in Figure 14, and overlaid on the shock location for $-8^{\circ}$. There was no noticeable change in the shock location, which was also observed in the pressure traces where levels of $\Delta \mathrm{P} / \mathrm{P}$ for the boat-tail expansion were similar in magnitude.

Schlieren results are also presented from the $8^{\circ}$ vector angle case in Figure 17. This image demonstrates that the shock location moves and changes angle to a very small degree, due to the dominant effects of the boat-tail angle on the nozzle lip shock location.

The effects of increasing NPR are presented in Figure 18 at an NPR of 12. The lip shock location is again highlighed and then superimposed on Figure 19, which is an image at a very high NPR value of 25 . NPRs above 12 were needed to get the nozzle lip shock to have a noticeable movement, as was demonstrated in previous experiments and analyses. As NPR was increased from 12 to 25 , the lip shock moved forward and changed angle with respect to the nozzle centerline. This result was confirmed in measurements, see Figure 12, where the nozzle boat-tail expansion was not as strong and the minimum $\Delta \mathrm{P} / \mathrm{P}$ value increased from -0.35 to -0.29 . 


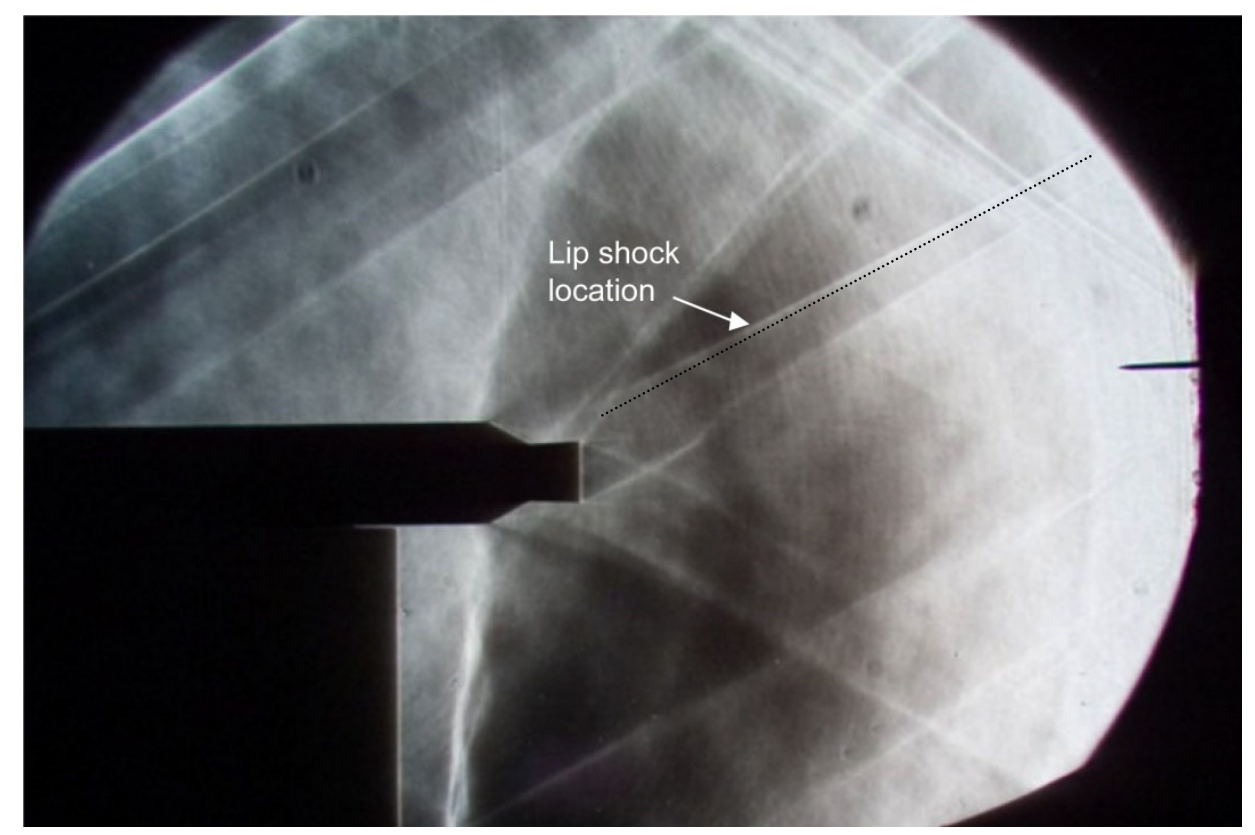

Figure $14 .-0^{\circ}$ vector angle nozzle schlieren image, NPR 8.

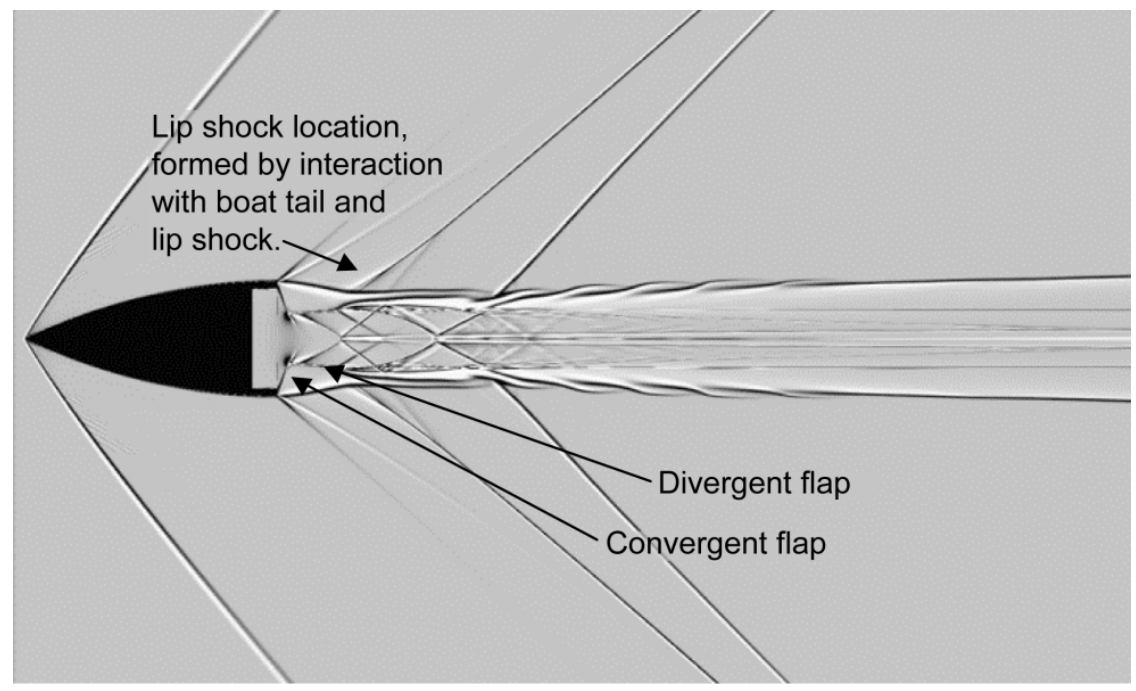

Figure 15. $-0^{\circ}$ vector angle nozzle CFD from Bui (Ref. 10). 


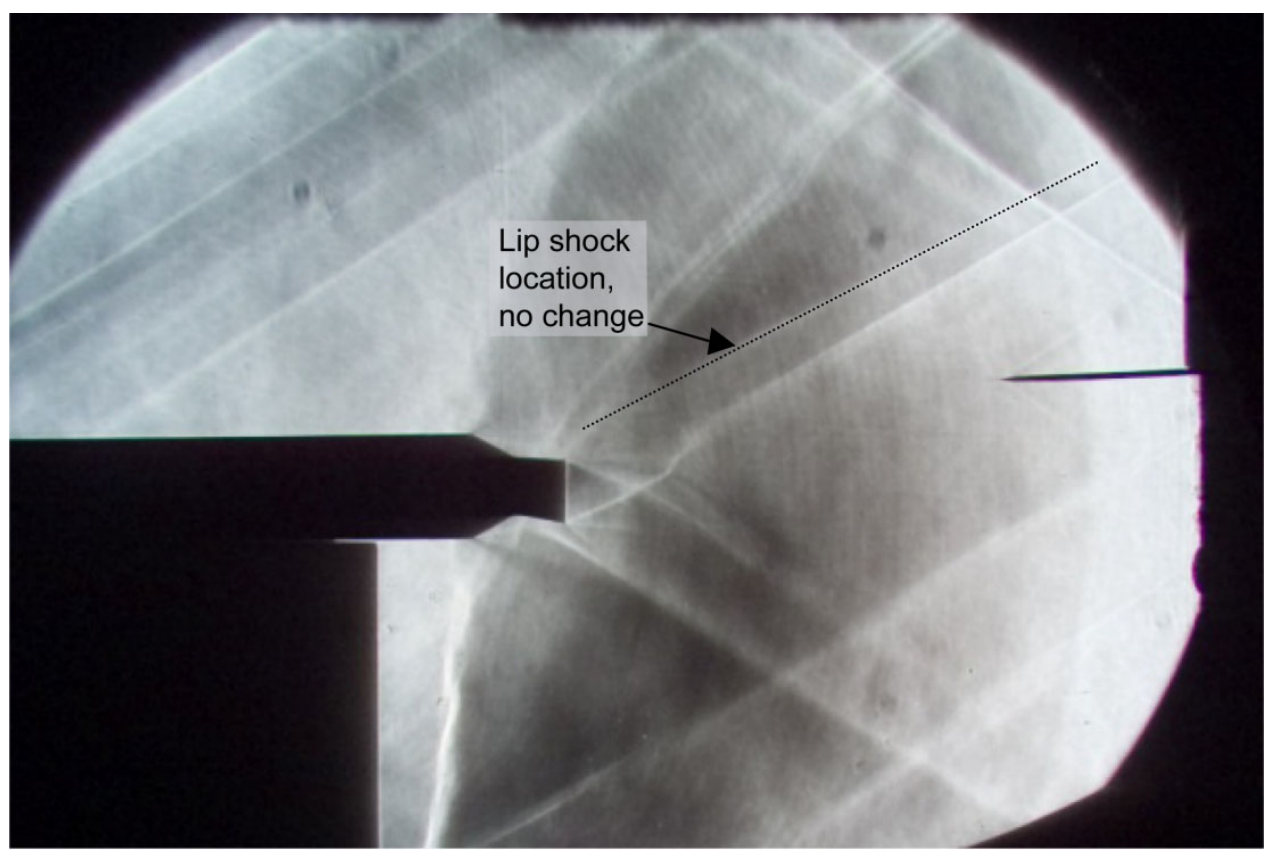

Figure 16.-Minus $8^{\circ}$ vectored nozzle schlieren image, NPR 8.

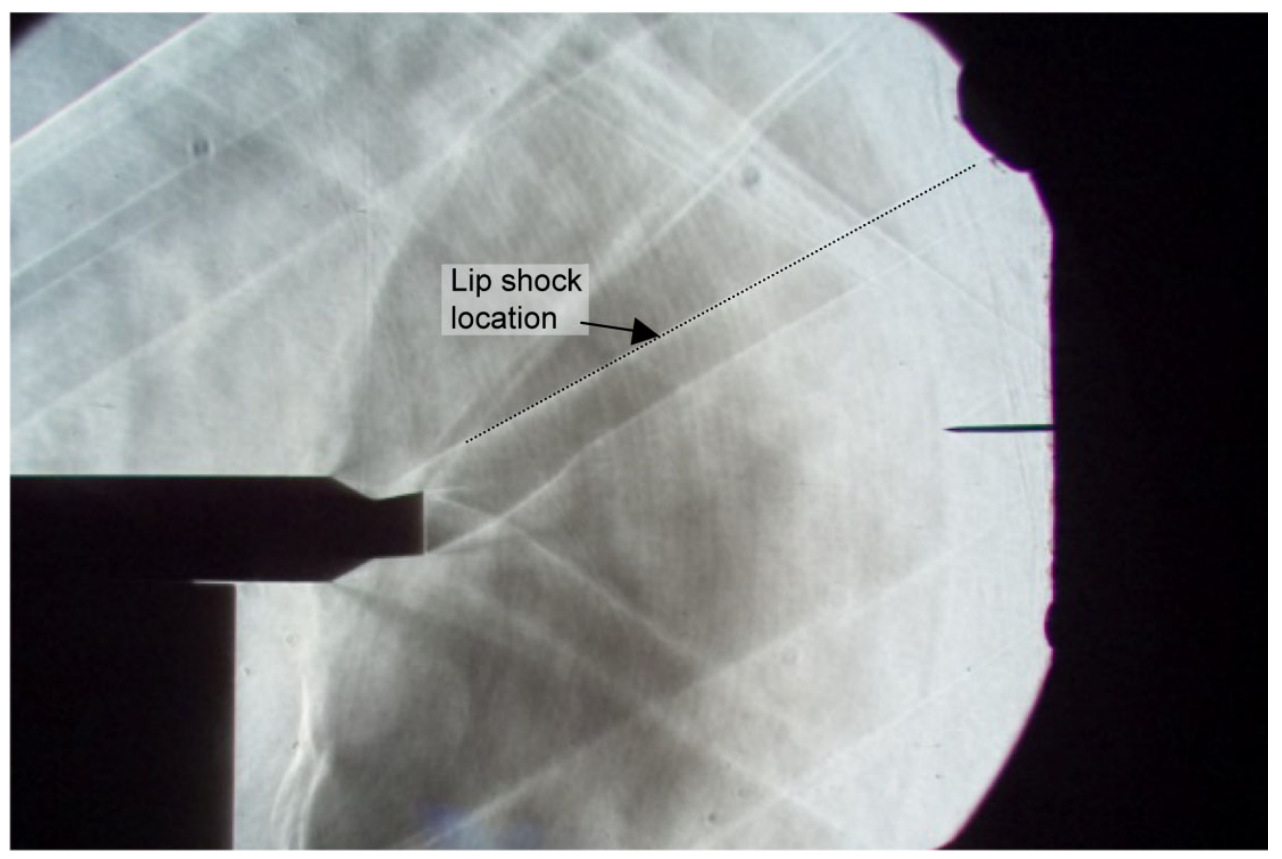

Figure 17.—Plus $8^{\circ}$ vectored nozzle schlieren image, NPR 8. 


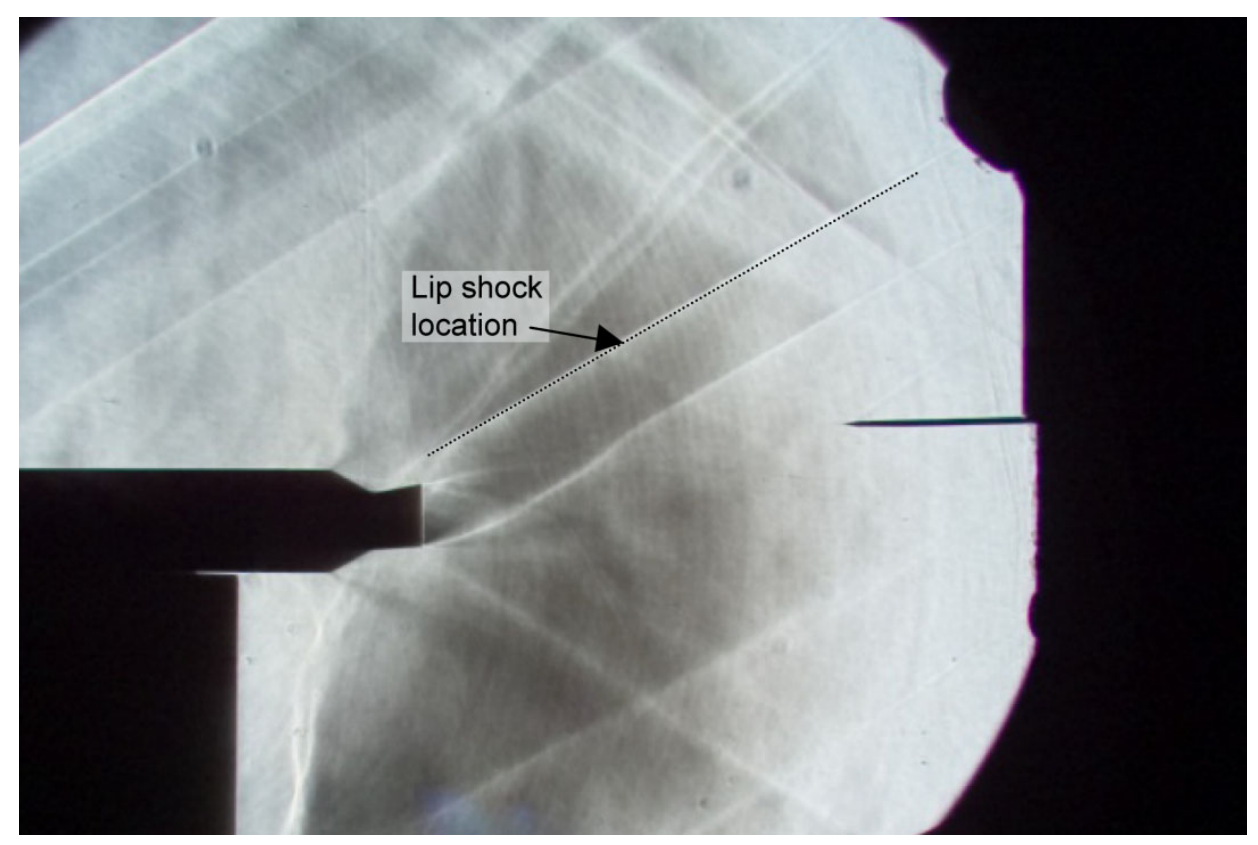

Figure 18.-Sample schlieren images of $8^{\circ}$ vectored nozzle plume for NPR 12.

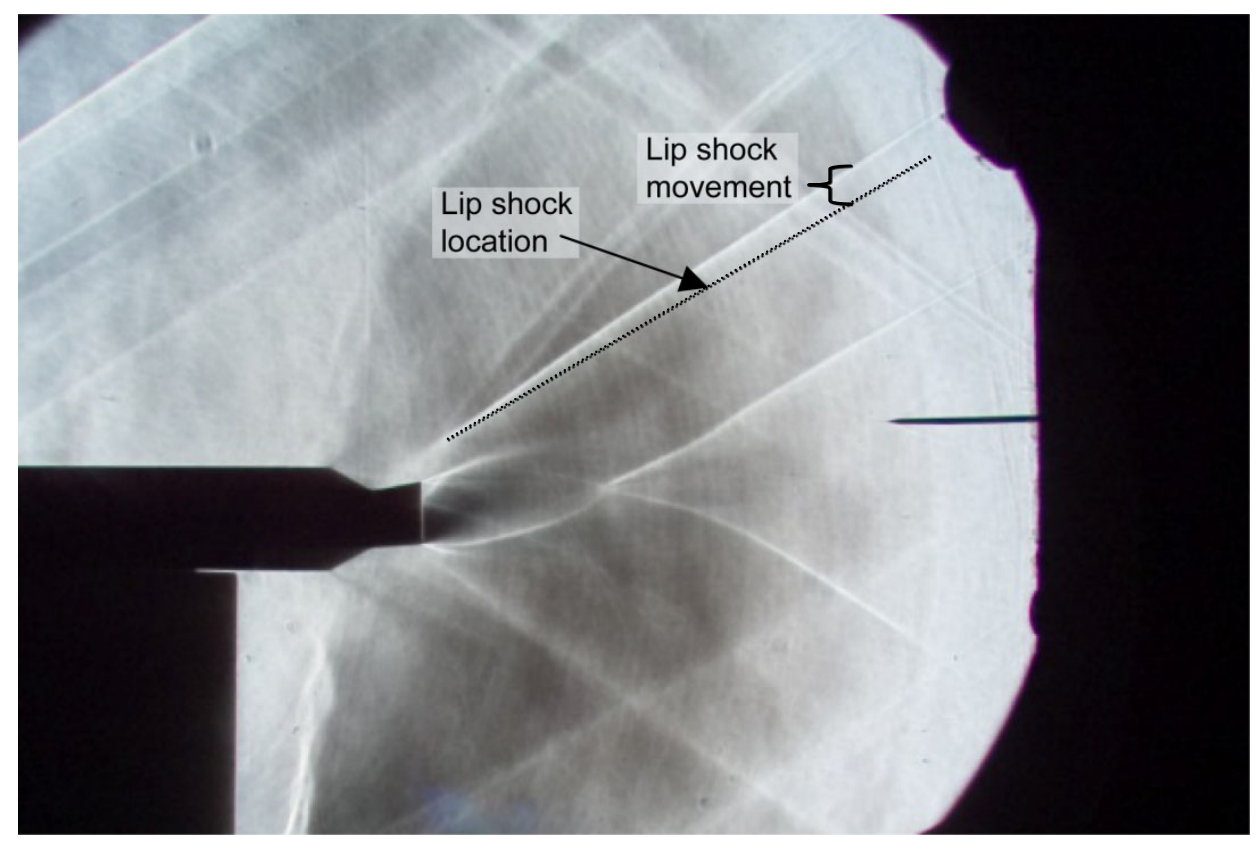

Figure 19.-Sample schlieren images of $8^{\circ}$ vectored nozzle plume for NPR 25. 


\subsection{Conclusions}

Background was provided on vectored nozzles used to study nozzle plume effects on sonic boom. Previous analysis and experiments showed how a shock wave formed at the nozzle lip and interacted with the nozzle boat-tail expansion.

An experiment was designed and conducted in the 1- by 1-foot Supersonic Wind Tunnel. The wind tunnel model consisted of a test nozzle supported by an upper plenum and strut. Instrumentation allowed calculation of NPR and measurement of near-field static pressure, presented as $\Delta \mathrm{P} / \mathrm{P}_{\infty}$. Schlieren images and flow visualization were used to validate proper placement of the model in the wind tunnel to avoid shock reflections and provide for a clean nozzle flow-field.

Results were similar to previous experiments where the near field pressure dropped as flow expanded around the nozzle boat-tail. This expansion was followed by a rapid pressure rise due to the shock at the nozzle lip, and was followed by a secondary expansion and shock around the nozzle plume. As NPR was increased, the pressure rise due to the lip shock increased. As the nozzle was vectored down, the magnitude of the lip shock decreased, while trends with increasing NPR remained the same. As the nozzle was vectored up, or towards the measurement plane, the magnitude of the lip shock strengthened. Trends again remained the same as NPR was increased.

For small changes in NPR, the changes in the nozzle shock location did not affect the boat-tail expansion, as they did in previous results. This was due to the severe boat-tail angle for this geometry, which caused a large separation and expansion which dominated the pressure signature. A change in this expansion pressure, which would reduce sonic boom, was not realized until very high NPR was set. In the case of this nozzle design, the boat-tail expansion was the dominant flow feature. Past work on nozzles with lower boat-tail angle showed that increasing NPR had an impact on the peak-to-peak level of the near field pressure signature. In this work, the vector angle was expected to have a similar effect and change the angle of the lip shock, but did not. Vectored nozzles with reduced boat-tail angle were not tested for comparison, but would make a valid follow on study. If vector angle were to be beneficial for sonic boom, the shock location for the lip shock would need to interrupt the expansion wave from the nozzle boat-tail, as demonstrated in previous studies.

The wind tunnel test results are consistent with the LaNCETS flight test data, where significant effects were not present due to vectoring the nozzle up and down at $3^{\circ}, 6^{\circ}$, and $8^{\circ}$ of vector angle. While this experiment was not a direct comparison due to differences in aircraft geometry and flight Mach number, it demonstrates consistency between the fundamental research and the flight test demonstration.

\section{References}

1. Graham, D., et al.: Aerodynamic Design of Shaped Sonic Boom Demonstration Aircraft. AIAA-2005-0009, 2005.

2. Freund, D., et al.: Quiet Spike Prototype Aerodynamic Characteristics From Flight Test. AIAA-2008-125, 2005.

3. Moes, T.: Sonic Boom Research at NASA Dryden: Objectives and Flight Results from the Lift and Nozzle Change Effects on tail Shock (LaNCETS) Project, International Test \& Evaluation Association, Feb. 2009.

4. Putnam, L. and Capone, F.: Experimental Determination of Equivalent Solid Bodies to Represent Jets Exhausting into a Mach 2.20 External Stream, NASA TN-D-5553.

5. Barger, R.L. and Melson, N.D.: Comparison of Jet Plume Shape Predictions and Plume Influence on Sonic Boom Signature, NASA TP-3172.

6. Castner, R.S.: Analysis of Plume Effects on Sonic Boom Signature for Isolated Nozzle Configurations, NASA/TM-2008-215414.

7. Blevins, R.D.: Applied Fluid Dynamics Handbook, Krieger, Florida, 1992 pp. 126-135. 
8. Pinckney, S.Z.: A Short Static Pressure Probe Design for Supersonic Flow, NASA TN D-7978.

9. Castner, R.S.: Exhaust Nozzle Plume Effects on Sonic Boom Test Results for Isolated Nozzles, AIAA-2010-4936, 2010.

10. Bui, Trong T.: "Computational Fluid Dynamics Analysis of Nozzle Plume Effects on Sonic Boom Signature," AIAA Journal of Aircraft, Vol. 48, No. 2, March 2011, pp. 368-380. 


\begin{tabular}{|c|c|c|}
\hline \multicolumn{2}{|c|}{ REPORT DOCUMENTATION PAGE } & $\begin{array}{l}\text { Form Approved } \\
\text { OMB No. 0704-0188 }\end{array}$ \\
\hline \multicolumn{3}{|c|}{$\begin{array}{l}\text { The public reporting burden for this collection of information is estimated to average } 1 \text { hour per response, including the time for reviewing instructions, searching existing data sources, gathering and maintaining the } \\
\text { data needed, and completing and reviewing the collection of information. Send comments regarding this burden estimate or any other aspect of this collection of information, including suggestions for reducing this } \\
\text { burden, to Department of Defense, Washington Headquarters Services, Directorate for Information Operations and Reports (0704-0188), } 1215 \text { Jefferson Davis Highway, Suite } 1224 \text {, Anlington, VA } 22222-2302 \text {. } \\
\text { Respondents should be aware that notwithstanding any other provision of law, no person shall be subject to any penalty for failing to comply with a collection of information if it does not display a currently valid OMB } \\
\text { control number. } \\
\text { PLEASE DO NOT RETURN YOUR FORM TO THE ABOVE ADDRESS. }\end{array}$} \\
\hline $\begin{array}{l}\text { 1. REPORT DATE (DD-MM-YYYY) } \\
01-02-2012\end{array}$ & $\begin{array}{l}\text { 2. REPORT TYPE } \\
\text { Technical Memorandum }\end{array}$ & 3. DATES COVERED (From - To) \\
\hline \multirow{3}{*}{\multicolumn{2}{|c|}{$\begin{array}{l}\text { 4. TITLE AND SUBTITLE } \\
\text { Exhaust Nozzle Plume Effects on Sonic Boom Test Results for Vectored Nozzles }\end{array}$}} & 5a. CONTRACT NUMBER \\
\hline & & 5b. GRANT NUMBER \\
\hline & & 5c. PROGRAM ELEMENT NUMBER \\
\hline \multirow{3}{*}{\multicolumn{2}{|c|}{$\begin{array}{l}\text { 6. AUTHOR(S) } \\
\text { Castner, Raymond }\end{array}$}} & 5d. PROJECT NUMBER \\
\hline & & 5e. TASK NUMBER \\
\hline & & $\begin{array}{l}\text { 5f. WORK UNIT NUMBER } \\
\text { WBS 984754.02.07.03.13.05 }\end{array}$ \\
\hline \multicolumn{2}{|c|}{$\begin{array}{l}\text { 7. PERFORMING ORGANIZATION NAME(S) AND ADDRESS(ES) } \\
\text { National Aeronautics and Space Administration } \\
\text { John H. Glenn Research Center at Lewis Field } \\
\text { Cleveland, Ohio 44135-3191 }\end{array}$} & $\begin{array}{l}\text { 8. PERFORMING ORGANIZATION } \\
\text { REPORT NUMBER } \\
\text { E-17790 }\end{array}$ \\
\hline \multirow{2}{*}{\multicolumn{2}{|c|}{$\begin{array}{l}\text { 9. SPONSORING/MONITORING AGENCY NAME(S) AND ADDRESS(ES) } \\
\text { National Aeronautics and Space Administration } \\
\text { Washington, DC 20546-0001 }\end{array}$}} & $\begin{array}{l}\text { 10. SPONSORING/MONITOR'S } \\
\text { ACRONYM(S) } \\
\text { NASA }\end{array}$ \\
\hline & & $\begin{array}{l}\text { 11. SPONSORING/MONITORING } \\
\text { REPORT NUMBER } \\
\text { NASA/TM-2012-217229 }\end{array}$ \\
\hline \multicolumn{3}{|c|}{$\begin{array}{l}\text { 12. DISTRIBUTIONIAVAILABILITY STATEMENT } \\
\text { Unclassified-Unlimited } \\
\text { Subject Categories: } 01,05 \text {, and } 07 \\
\text { Available electronically at http://www.sti.nasa.gov } \\
\text { This publication is available from the NASA Center for AeroSpace Information, 443-757-5802 }\end{array}$} \\
\hline
\end{tabular}

\section{SUPPLEMENTARY NOTES}

\section{ABSTRACT}

Reducing or eliminating the operational restrictions of supersonic aircraft over populated areas has led to extensive research at NASA. Restrictions were due to the disturbance of the sonic boom, caused by the coalescence of shock waves formed off the aircraft. Recent work has been performed to reduce the magnitude of the sonic boom $\mathrm{N}$-wave generated by airplane components with a focus on shock waves caused by the exhaust nozzle plume. Previous Computational Fluid Dynamics (CFD) analysis showed how the shock wave formed at the nozzle lip interacts with the nozzle boat-tail expansion wave. An experiment was conducted in the 1- by 1-foot Supersonic Wind Tunnel (SWT) at the NASA Glenn Research Center. Results show how the shock generated at the nozzle lip affects the near field pressure signature, and thereby the potential sonic boom contribution for a nozzle at vector angles from $3^{\circ}$ to $8^{\circ}$. The experiment was based on the NASA F-15 nozzle used in the Lift and Nozzle Change Effects on Tail Shock experiment, which possessed a large external boat-tail angle. In this case, the large boat-tail angle caused a dramatic expansion, which dominated the near field pressure signature. The impact of nozzle vector angle and nozzle pressure ratio are summarized.

\section{SUBJECT TERMS}

Exhaust nozzles; Plumes; Sonic booms

\begin{tabular}{|c|c|c|c|c|c|}
\hline \multicolumn{3}{|c|}{ 16. SECURITY CLASSIFICATION OF: } & \multirow{2}{*}{$\begin{array}{l}\text { 17. LIMITATION OF } \\
\text { ABSTRACT } \\
\text { UU }\end{array}$} & \multirow{2}{*}{$\begin{array}{l}\text { 18. NUMBER } \\
\text { OF } \\
\text { PAGES } \\
22\end{array}$} & \multirow{2}{*}{$\begin{array}{l}\text { 19a. NAME OF RESPONSIBLE PERSON } \\
\text { STI Help Desk (email:help@sti.nasa.gov) } \\
\text { 19b. TELEPHONE NUMBER (include area code) } \\
\text { 443-757-5802 }\end{array}$} \\
\hline $\begin{array}{l}\text { a. REPORT } \\
\text { U }\end{array}$ & $\begin{array}{l}\text { b. ABSTRACT } \\
\mathrm{U}\end{array}$ & $\begin{array}{l}\text { c. THIS } \\
\text { PAGE } \\
\text { U }\end{array}$ & & & \\
\hline
\end{tabular}


